\title{
Investigations of anticholinestrase and antioxidant potentials of methanolic extract, subsequent fractions, crude saponins and flavonoids isolated from Isodon rugosus
}

Anwar Zeb, Abdul Sadiq ${ }^{*}$, Farhat Ullah, Sajjad Ahmad and Muhammad Ayaz

\begin{abstract}
Background: Based on the ethnomedicinal uses and the effective outcomes of natural products in various diseases, this study was designed to evaluate Isodon rugosus as possible remedy in oxidative stress, alzheimer's and other neurodegenerative diseases. Acetylecholinestrase (AChE) and butyrylcholinesterase (BChE) inhibitory activities of crude methanolic extract (Ir.Cr), resultant fractions ( $n$-hexane (Ir.Hex), chloroform (Ir.Cf), ethyl acetate (Ir.EtAc), aqueous (Ir.Aq)), flavonoids (Ir.Flv) and crude saponins (Ir.Sp) of I. rugosus were investigated using Ellman's spectrophotometric method. Antioxidant potential of I. rugosus was determined using DPPH, $\mathrm{H}_{2} \mathrm{O}_{2}$ and ABTS free radicals scavenging assays. Total phenolic and flavonoids contents of plant extracts were determined and expressed in mg GAE/g dry weight and mg RTE/g of dry sample respectively.

Results: Among different fractions Ir.Flv and Ir.Cf exhibited highest inhibitory activity against AChE $(87.44 \pm 0.51$, $83.73 \pm 0.64 \%)$ and $B C h E(82.53 \pm 0.71,88.55 \pm 0.77 \%)$ enzymes at $1 \mathrm{mg} / \mathrm{ml}$ with $\mathrm{IC}_{50}$ values of 45,50 for AChE and $40,70 \mathrm{\mu g} / \mathrm{ml}$ for $\mathrm{BChE}$ respectively. Activity of these fractions were comparable to galanthamine causing $96.00 \pm 0.30$ and $88.61 \pm 0.43 \%$ inhibition of $A C h E$ and BChE at $1 \mathrm{mg} / \mathrm{ml}$ concentration with $I C_{50}$ values of 20 and $47 \mu \mathrm{g} / \mathrm{ml}$ respectively. In antioxidant assays, Ir.Flv, Ir.Cf, and Ir.EtAc demonstrated highest radicals scavenging activities in DPPH and $\mathrm{H}_{2} \mathrm{O}_{2}$ assays which were comparable to ascorbic acid. Ir.Flv was found most potent with $\mathrm{IC}_{50}$ of 19 and $24 \mathrm{\mu g} / \mathrm{ml}$ against DPPH and $\mathrm{H}_{2} \mathrm{O}_{2}$ radicals respectively. Whereas antioxidant activates of plant samples against ABTS free radicals was moderate. Ir.Cf, Ir.EtAc and Ir.Cr showed high phenolic and flavonoid contents and concentrations of these compounds in different fractions correlated well to their antioxidant and anticholinestrase activities.
\end{abstract}

Conclusion: It may be inferred from the current investigations that the Ir.Sp, Ir.Flv and various fractions of I. rugosus are good sources of anticholinesterase and antioxidant compounds. Different fractions can be subjected to activity guided isolation of bioactive compounds effective in neurological disorders.

Keywords: Anticholinesterase, Antioxidant, Flavonoids, Phenolics, Saponins, Isodon rugosus

* Correspondence: sadiquom@yahoo.com

Department of Pharmacy, University of Malakand, Chakdara, Dir, Pakistan 


\section{Background}

Alzheimer's disease (AD) is a chronic neurodegenerative disorder effecting more than twenty millions people globally and is the most common cause of dementia in elder population [1,2]. AD is characterized by degeneration of neurological function, presence of extra-neuronal amyloid deposits, neuritic plaques, gradual deficits in various neurotransmitters leading to decline in the levels of acetylcholine (ACh) and loss of cognitive abilities [1]. Inhibitors of acetylecholinestrase (AChE) and butyrylcholinestrase $(\mathrm{BChE})$, key enzymes involved in the degradation of neurotransmitter $\mathrm{ACh}$, have been shown to function by restoring the level of $\mathrm{ACh}$ in the synaptic region and thus reinstate deficient cholinergic neurotransmission [3,4]. Since the discovery of cholinergic deficits in patients suffering from neurological disorders, inhibition of these enzymes is the main target in the treatment of $\mathrm{AD}$, senile dementia, Parkinsonism, ataxia and myasthenia gravis $[5,6]$. Synthetic drugs used in the treatment of cognitive dysfunction associated with $\mathrm{AD}$ and other diseases include tacrine, donepezil and rivastigmine [7]. But these drugs are associated with adverse effects including gastrointestinal disturbances, hepatotoxicity and bioavailability problems [8,9], which necessitates the development of better $\mathrm{AChE}$ and $\mathrm{BChE}$ inhibitors from natural resources i.e. galantamine.

Reactive oxygen species (ROS) are produced during aerobic respiration and other redox processes in the body. These ROS can attack some important biomolecules like enzymes, lipids, proteins, DNA and RNA leading to cellular damage and plays a major role in aging process [10]. To counteract oxidative stress, human body has several defense mechanisms including antioxidant enzymes and non-enzymatic compounds. But excess of free radicals make the organism unable to scavenge all ROS. These ROS are implicated in the development of some chronic diseases including cardiovascular diseases, cancer, diabetes, nephritis, rheumatism and aging. Oxidative stress has been reported to play a key role in the progression of neurodegenerative diseases like AD and Parkinson's disease [11,12]. Generally consumption of herbs, fruits and vegetables are beneficial for health due to the presence of protective antioxidant phyto-nutrients present in them $[13,14]$. Synthetic antioxidant compounds including gallic acid esters, butylated hydroxy toluene (BHT), tertiary butylated hydroquinone and butylated hydroxy anisole (BHA) are associated with severe adverse effects and hence their use is limited. Consequently, there is need to discover new antioxidants from natural sources [15]. In this regard antioxidant potential of numerous plants has been reported [16-19]. In antioxidant compounds, flavonoids and phenolic compounds are very important. These compounds has the ability to scavenge free radicals effectively due to the presence of hydroxyl groups and conjugated system [20].
I. rugosus belongs to Labiateae, a family rich in species containing huge number of pharmacologically active compounds. The Isodon species are traditionally used as anticancer, antimicrobial, insecticidal, antioxidants and as anthelmintic [21-24]. I. rugosus is used traditionally in the management of hypertension, rheumatism, toothache, and pyrexia [25]. Ethno-medicinally, this is used in the treatment of skin diseases, ear, nose and throat infections and the treatment of intestinal disorders are also reported [26]. In an effort to discover new sources which can potentially be used in the treatment of oxidative stress, $\mathrm{AD}$ and other neurological disorders, I. rugosus was investigated for anticholinesterase and antioxidant potentials.

\section{Results}

Total phenolic and flavonoid contents

Results of total phenolic and flavonoids contents in different fractions of $I$. rugosus are summarized in Table 1. Results indicate that Ir.Cf, Ir.EtAc and Ir.Cr exhibited high phenolic contents, i.e. $82.60 \pm 0.68,67.45 \pm 0.83$ and $65.51 \pm 1.67 \mathrm{mg} \mathrm{GAE} / \mathrm{g}$ of dry sample respectively. Whereas, Ir.Cf, Ir.Cr and Ir.EtAc showed highest flavonoids content i.e. $91.45 \pm 1.12,71.73 \pm 0.69$ and $68.46 \pm$ $1.83 \mathrm{mg} \mathrm{RTE} / \mathrm{g}$ of sample respectively. Phenolic compounds show greater antioxidant activity due to the presence of hydroxyl groups and conjugated system in their chemical strucutre $[27,28]$. Phenolic and flavonoid contents in different fractions of plant correlated well to the antioxidant activity.

\section{Anticholinesterase assays}

Results of AChE and BChE inhibitory potentials of I. rugosus at various tested concentrations are summarized in Table 2. In AChE inhibition assay, Ir.Flv, Ir.Cf and Ir.Sp showed highest activity against AChE causing $87.44 \pm 0.51,83.73 \pm 0.64$ and $77.85 \pm 0.56 \%$ inhibitions at $1 \mathrm{mg} / \mathrm{ml}$ respectively. For these fractions $\mathrm{IC}_{50}$ values were 45,50 and $75 \mu \mathrm{g} / \mathrm{ml}$ respectively. Standard drug galanthamine inhibited AChE enzyme by $96.00 \pm 0.30 \%$ at $1 \mathrm{mg} / \mathrm{ml}$ concentration with $\mathrm{IC}_{50}$ value of $20 \mu \mathrm{g} / \mathrm{ml}$.

$\begin{aligned} & \text { Table } \mathbf{1} \text { Total } \text { phenolics and total flavonoids of } \mathbf{~ r . C r} \text { and } \\
& \text { subfractions of } \boldsymbol{I} \text {. } \text { rugosus }\end{aligned}$
\begin{tabular}{lcc}
\hline Samples & $\begin{array}{l}\text { Total phenolics } \\
\text { (mg GAE/g of sample) }\end{array}$ & $\begin{array}{l}\text { Total flavonoids } \\
\text { (mg RTE/g of sample) }\end{array}$ \\
\hline Ir.Cr & $65.51 \pm 1.67$ & $71.73 \pm 0.69$ \\
Ir.Hex & $41.38 \pm 1.15$ & $44.40 \pm 2.76$ \\
Ir.Cf & $82.60 \pm 0.68$ & $91.45 \pm 1.12$ \\
Ir.EtAc & $67.45 \pm 0.83$ & $68.46 \pm 1.83$ \\
Ir.Aq & $18.11 \pm 2.25$ & $27.12 \pm 1.33$ \\
\hline
\end{tabular}

Each value in the table is represented as mean $\pm \mathrm{SEM}(\mathrm{N}=3)$.

Abbreviations: Ir. Cr Crude methanolic extract, Ir.Hex $n$-hexane fraction, Ir.Cf Chloroform fraction, Ir.EtAc Ethyl acetate fraction, Ir.Aq Aqueous fraction. 
Table 2 Percent AChE and BChE inhibition potentials of I. rugosus at various tested concentrations

\begin{tabular}{|c|c|c|c|c|c|}
\hline Samples & $\begin{array}{l}\text { Concentrations } \\
(\mu \mathrm{g} / \mathrm{ml})\end{array}$ & $\begin{array}{l}\text { Percent AChE } \\
\text { (mean } \pm \text { SEM) }\end{array}$ & $\begin{array}{l}\text { AChE } \\
\mathrm{IC}_{50} \\
(\mu \mathrm{g} / \mathrm{ml})\end{array}$ & $\begin{array}{l}\text { Percent } \\
\text { BChE } \\
\text { (mean } \pm \text { SEM) }\end{array}$ & $\begin{array}{l}\text { BChE } \\
\mathrm{IC}_{50} \\
(\mu \mathrm{g} / \mathrm{ml})\end{array}$ \\
\hline \multirow[t]{3}{*}{$\operatorname{lr} . S p$} & 1000 & $77.85 \pm 0.56^{* * *}$ & & $69.48 \pm 0.74^{* * *}$ & \\
\hline & 500 & $71.64 \pm 0.75^{* * *}$ & 75 & $62.62 \pm 0.40^{* * *}$ & 210 \\
\hline & 250 & $62.58 \pm 0.77^{* * *}$ & & $51.60 \pm 0.46^{* * *}$ & \\
\hline \multirow[t]{3}{*}{$\operatorname{lr} \cdot \mathrm{Cr}$} & 1000 & $71.75 \pm 0.63^{* * *}$ & & $68.68 \pm 0.49^{* * *}$ & \\
\hline & 500 & $63.58 \pm 0.70^{* * *}$ & 140 & $61.72 \pm 0.66^{* * *}$ & 145 \\
\hline & 250 & $56.61 \pm 0.53^{* * *}$ & & $55.46 \pm 0.63^{* * *}$ & \\
\hline \multirow[t]{3}{*}{ Ir.Hex } & 1000 & $64.79 \pm 0.62^{* * *}$ & & $62.61 \pm 0.77^{* * *}$ & \\
\hline & 500 & $45.45 \pm 0.49^{* * *}$ & 630 & $54.60 \pm 0.80^{* * *}$ & 380 \\
\hline & 250 & $43.75 \pm 0.58^{* * *}$ & & $43.83 \pm 0.56^{* * *}$ & \\
\hline \multirow[t]{3}{*}{ Ir.Cf } & 1000 & $83.73 \pm 0.64^{* * *}$ & & $88.55 \pm 0.77^{\mathrm{ns}}$ & \\
\hline & 500 & $79.47 \pm 0.56^{* * *}$ & 50 & $83.65 \pm 0.77^{\mathrm{ns}}$ & 70 \\
\hline & 250 & $67.81 \pm 0.60^{* * *}$ & & $67.58 \pm 0.74^{* * *}$ & \\
\hline \multirow[t]{3}{*}{ Ir.EtAc } & 1000 & $71.74 \pm 0.61^{* * *}$ & & $76.37 \pm 0.68^{* * *}$ & \\
\hline & 500 & $69.68 \pm 0.60^{* * *}$ & 170 & $72.66 \pm 0.78^{* * *}$ & 52 \\
\hline & 250 & $52.63 \pm 0.76^{* * *}$ & & $63.62 \pm 0.74^{* * *}$ & \\
\hline \multirow[t]{3}{*}{ Ir.Aq } & 1000 & $66.79 \pm 0.63^{* * *}$ & & $71.62 \pm 0.74^{* * *}$ & \\
\hline & 500 & $59.67 \pm 0.61^{* * *}$ & 340 & $63.86 \pm 0.60^{* * *}$ & 305 \\
\hline & 250 & $41.69 \pm 0.77^{* * *}$ & & $44.48 \pm 0.64^{* * *}$ & \\
\hline \multirow[t]{3}{*}{ Ir.Flv } & 1000 & $87.44 \pm 0.51^{* * *}$ & & $82.53 \pm 0.71^{* * *}$ & \\
\hline & 500 & $73.76 \pm 0.58^{* * *}$ & 45 & $76.52 \pm 0.68^{* * *}$ & 40 \\
\hline & 250 & $71.54 \pm 0.50^{* * *}$ & & $68.51 \pm 0.77^{* * *}$ & \\
\hline \multirow[t]{3}{*}{ Galanthamine } & 1000 & $96.00 \pm 0.30$ & & $88.61 \pm 0.43$ & \\
\hline & 500 & $91.26 \pm 1.27$ & 20 & $83.25 \pm 1.40$ & 47 \\
\hline & 250 & $82.91 \pm 1.30$ & & $74.03 \pm 0.86$ & \\
\hline
\end{tabular}

The data is represented as mean $\pm \mathrm{SEM},(\mathrm{N}=3)$. Values significantly different as compare to positive control, * $\mathrm{P}<0.05$, **P $\mathrm{P}<0.01,{ }^{* * *} \mathrm{P}<0.001$.

Abbreviations: Ir.Cr Crude methanolic extract, Ir.Hex $n$-hexane fraction, Ir.Cf Chloroform fraction, Ir.EtAc Ethyl acetate fraction, Ir.Aq Aqueous fraction, Ir.Flv Crude flavonoids, Ir.Sp Crude Saponins.

Percent inhibitions of these fractions were comparable to the standard drug. AChE inhibition activity of all other fractions was less than $60 \%$. On the other hand, Ir.Cf, Ir.Flv and Ir.EtAc were most effective fractions against BChE enzyme, causing $88.55 \pm 0.77,82.53 \pm$ 0.71 and $76.37 \pm 0.68 \%$ inhibitions at $1 \mathrm{mg} / \mathrm{ml}$ concentration respectively. Ir.Cf, Ir.Flv and Ir.EtAc were most potent, presenting $\mathrm{IC}_{50}$ of 70,40 and $52 \mu \mathrm{g} / \mathrm{ml}$ respectively. BChE inhibitory activities of these fractions were comparable to galanthamine result with percent inhibition of $88.61 \pm 0.43 \%$ at $1 \mathrm{mg} / \mathrm{ml}$ with $\mathrm{IC}_{50}$ value of $47 \mu \mathrm{g} / \mathrm{ml}$.

\section{Antioxidant assays}

\section{$D P P H$ free radicals scavenging effect}

Analysis of plant samples against DPPH free radicals revealed that Ir.Flv, Ir.Sp, Ir.EtAc and Ir.Cf were most effective causing $81.1 \pm 0.90,76.36 \pm 0.48,74.53 \pm 1.34$ and
$71.63 \pm 0.67 \%$ scavenging respectively at $1 \mathrm{mg} / \mathrm{ml}$ concentration. Median inhibitory concentrations $\left(\mathrm{IC}_{50}\right)$ were 19, < 0.1, 22 and $28 \mu \mathrm{g} / \mathrm{ml}$ for Ir.Flv, Ir.Sp, Ir.EtAc and Ir.Cf respectively as shown in Figure 1. Ascorbic acid (Positive control) cause $85.71 \pm 0.49 \%$ inhibition of DPPH radicals at $1 \mathrm{mg} / \mathrm{ml}$ concentration and $\mathrm{IC}_{50}$ was $52 \mu \mathrm{g} / \mathrm{ml}$. Potency wise activity of Ir.Flv, Ir.Sp, Ir.EtAc and Ir.Cf was better than ascorbic acid. Other fractions were effective in concentration dependent manner. DPPH scavenging activity for all the tested samples were in ascending order of Ir.Flv $>$ Ir.EtAc $>$ Ir.Cf $>$ Ir.Cr $>$ Ir.Aq $>$ Ir.Hex, shown in Figure 2.

\section{Hydrogen peroxide free radicals scavenging effect}

In $\mathrm{H}_{2} \mathrm{O}_{2}$ free radicals scavenging activity, Ir.Flv, Ir.EtAc, Ir.Sp, Ir.Cf and Ir.Cr showed highest activities causing $78.9 \pm 0.41,74.1 \pm 0.67,69.5 \pm 0.67,69.50 \pm 0.67$ and $64.4 \pm$ $0.64 \%$ inhibition at $1 \mathrm{mg} / \mathrm{ml}$ concentration (Figure 3). 


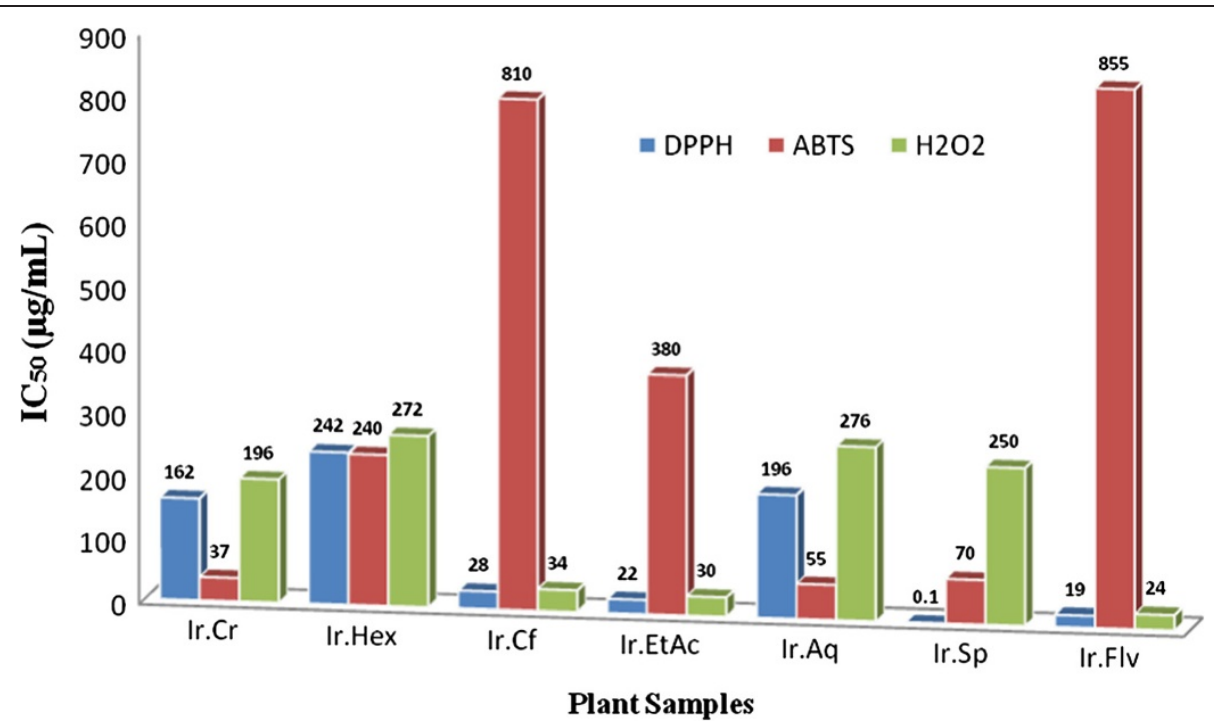

Figure 1 IC50 values of various samples against DPPH, H2O2 and ABTS free radicals. Abbreviations: Ir.Cr: Crude methanolic extract; Ir.Hex: n-hexane fraction; Ir.Cf: Chloroform fraction; Ir.EtAc: Ethyl acetate fraction; Ir.Aq: Aqueous fraction; Ir.Flv: Crude flavonoids; Ir.Sp: Crude Saponins.

For these fractions $\mathrm{IC}_{50}$ were 24, 30, 250, 34 and $196 \mu \mathrm{g} / \mathrm{ml}$ respectively, as shown in Figure 1. Ascorbic acid inhibition was $83.08 \pm 0.47 \%$ at the same tested concentration with $\mathrm{IC}_{50} 24 \mu \mathrm{g} / \mathrm{ml}$.

\section{ABTS free radicals scavenging effect}

In ABTS free radicals scavenging assay, Ir.Cr, Ir.Sp, Ir. Hex, Ir.EtAc and Ir.Flv showed highest activity causing $79.35 \pm 0.61,74.89 \pm 0.22,74.1 \pm 1.04,64.99 \pm 0.92$ and $57.04 \pm 1.12 \%$ scavenging respectively at $1 \mathrm{mg} / \mathrm{ml}$ concentration (Figure 4). For these fractions, the $\mathrm{IC}_{50}$ were 37, 70, 240 and $380 \mu \mathrm{g} / \mathrm{ml}$ respectively, as shown in Figure 1. The ascorbic acid inhibition was $84.78 \pm 0.40 \%$ at $1 \mathrm{mg} / \mathrm{ml}$ with $\mathrm{IC}_{50}$ of $50 \mu \mathrm{g} / \mathrm{ml}$.

Correlation of total phenolic contents and various activities Regression and correlation of total phenolic contents and various assays have been summarized in Figure 5 (A, B, C, $\mathrm{D}$ and $\mathrm{E})$. The correlation coefficient $\left(\mathrm{R}^{2}=0.742\right)$ obtained by plotting $\mathrm{H}_{2} \mathrm{O}_{2}$ scavenging assay versus total phenolic

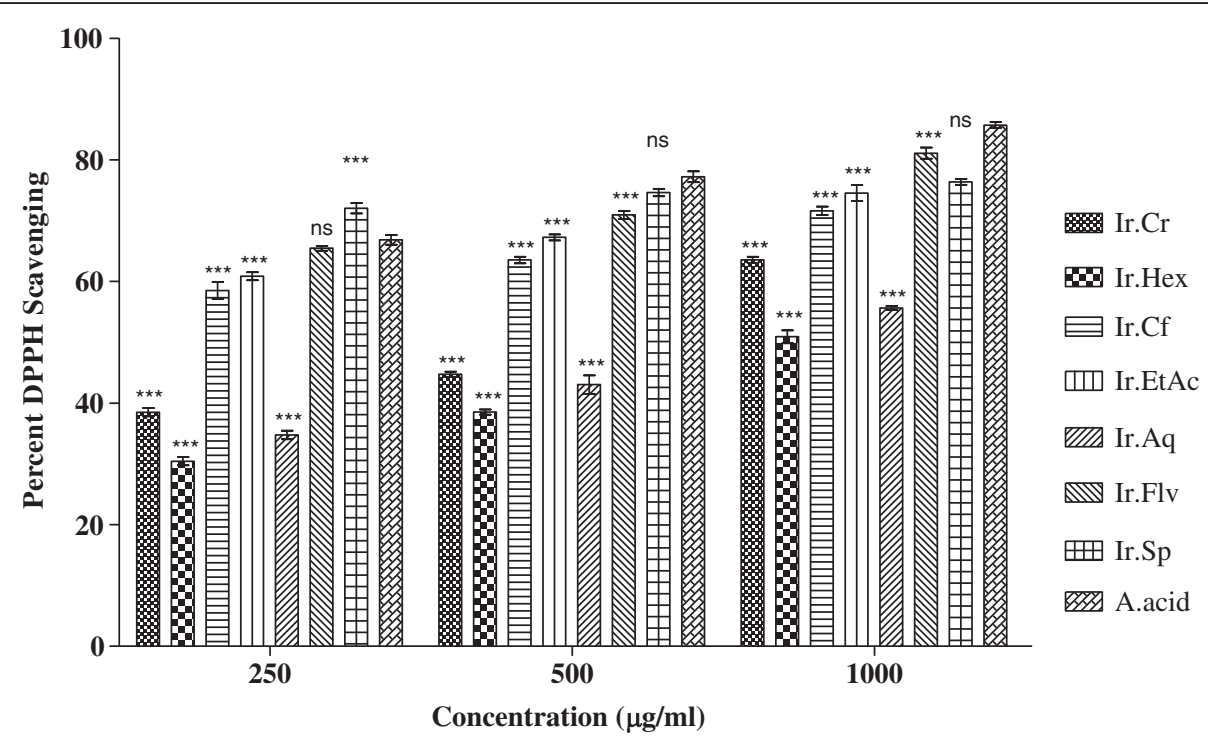

Figure 2 Antioxidant potential of plant extracts using DPPH assay. Values represent \% radical scavenging (mean \pm SEM) of three replicates. Values significantly different as compare to positive control ${ }^{*} \mathrm{P}<0.05$, ${ }^{* *} \mathrm{P}<0.01$, ${ }^{* *} \mathrm{P}<0.001$. Abbreviations: Ir.Cr: Crude methanolic extract; Ir. Hex: $n$-hexane fraction; Ir.Cf: Chloroform fraction; Ir.EtAc: Ethyl acetate fraction; Ir.Aq: Aqueous fraction; Ir.Flv: Crude flavonoids; Ir.Sp: Crude Saponins; A.acid: Ascorbic acid. 


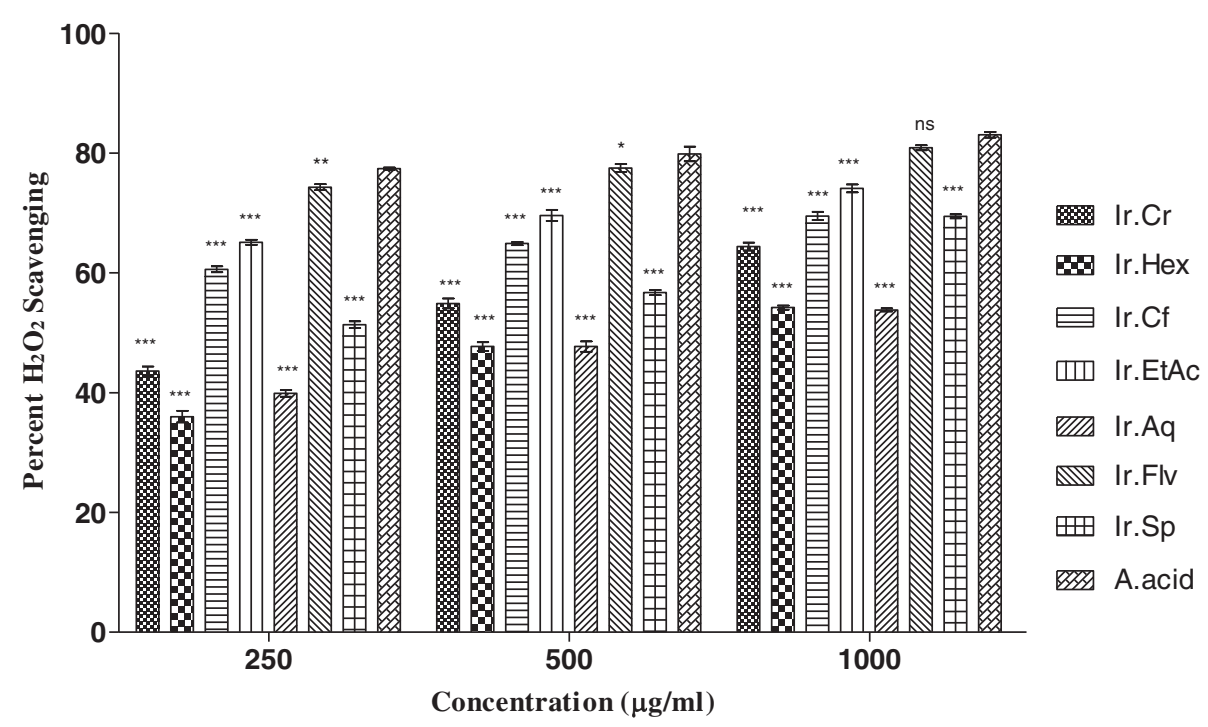

Figure 3 Antioxidant potential of plant extracts using $\mathrm{H}_{2} \mathrm{O}_{2}$ assay. Values represent \% radical scavenging (mean \pm SEM) of three replicates. Values significantly different as compare to positive control, ${ }^{*} P<0.05$, ${ }^{*} P<0.01$, ${ }^{* * * P}<0.001$. Abbreviations: Ir.Cr: Crude methanolic extract; Ir.Hex: $n$-hexane fraction; Ir.Cf: Chloroform fraction; Ir.EtAc: Ethyl acetate fraction; Ir.Aq: Aqueous fraction; Ir.Flv: Crude flavonoids; Ir.Sp: Crude Saponins; A.acid: Ascorbic acid.

contents was the most prominent one. The regression line for $\mathrm{H}_{2} \mathrm{O}_{2}(\mathrm{y}=0.312 \mathrm{x}+45.60)$ went parallel with the total phenolic contents. Similarly, the correlation co-efficients of ABTS and DPPH were calculated as 0.415 and 0.641 respectively. Furthermore, the regression line obtained for $\operatorname{AChE}(y=0.236 x+58.75)$ and $\operatorname{BChE}(y=0.240 x+$ $60.35)$ goes moderately parallel with the total phenolic contents having correlation coefficient 0.663 and 0.390 respectively.

\section{Discussion}

Antioxidant compounds are useful neuroprotective agents in the therapy of early stages of Alzheimer's disease (AD) [29]. Though exact origin of AD is unknown, the diminution of neurotransmitters like ACh caused by the enzymes $\mathrm{AChE}$ and $\mathrm{BChE}$ are clearly involved in the etiology of this disease [30]. One treatment strategy is to enhance cholinergic functions by the use of AChE and $\mathrm{BChE}$ inhibitors to augment the amount of ACh present

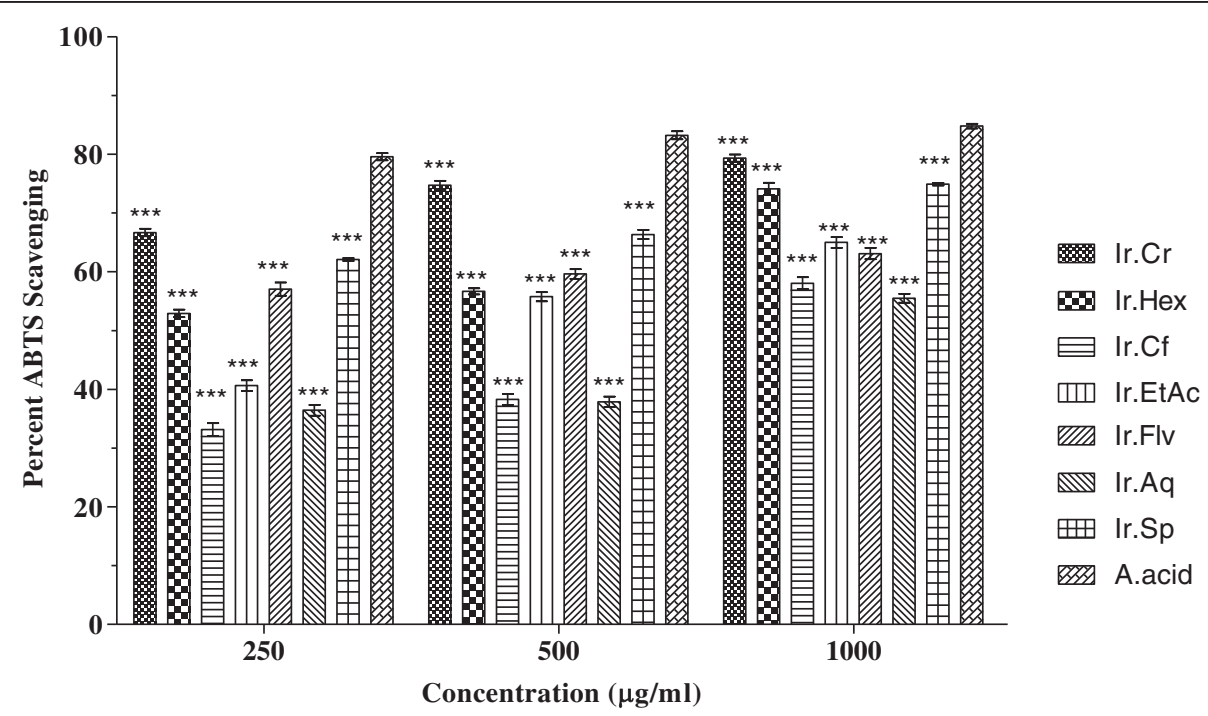

Figure 4 Antioxidant potential of plant extracts using ABTS assay. Values represent \% radical scavenging (mean \pm SEM) of three replicates. Values significantly different as compare to positive control, ${ }^{*} \mathrm{P}<0.05$, ${ }^{*} \mathrm{P}<0.01$, ${ }^{* *} \mathrm{P}<0.001$. Abbreviations: Ir.Cr: Crude methanolic extract; Ir.Hex: $n$-hexane fraction; Ir.Cf: Chloroform fraction; Ir.EtAc: Ethyl acetate fraction; Ir.Aq: Aqueous fraction; Ir.Flv: Crude flavonoids; Ir.Sp: Crude Saponins; A.acid: Ascorbic acid. 


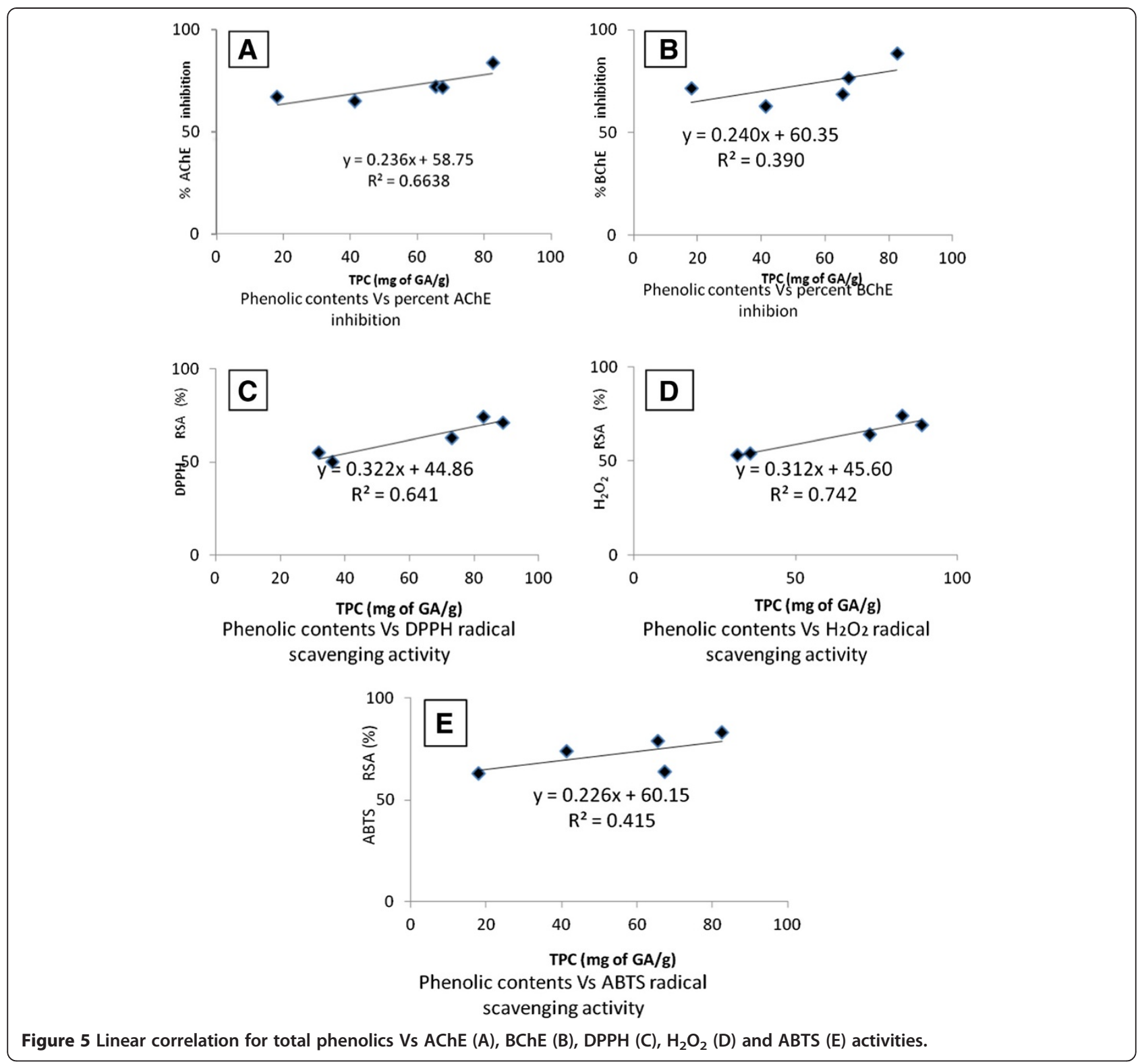

in the synapses between cholinergic neurons. In this regard, use of selective inhibitors for $\mathrm{AChE}$ and $\mathrm{BChE}$ has attracted particular attention in the treatment of the Alzheimer-type dementia [31]. In recent times, BChE received particular attention since it is a co-regulator of cholinergic neurotransmission and its pharmacological activity is increased in AD and associated with all neuropathological lesions in this disorder [32]. Even though selective inhibitors of BChE from synthetic origin, based on quinazolinimines and lipoic acid have been reported [33]. The search for more efficient and less expensive natural substances is a mandatory research branch [29]. Use of AChE inhibitors like physostigmine or tacrine is restricted due to limitations such as short half life and serious side effects like hepatotoxicity. Alkylpyridium polymers, dehydroevodiamine (DHED) and carbamate type AChE inhibitors have been recently reported, but due to bioavailability problems and side effects, there is still great interest in searching better $\mathrm{AChE}$ inhibitors from natural sources [34].

Results of the current study revealed that Ir.Flv, Ir.Cf and Ir.Sp possesses highest inhibitory potential against AChE causing $87.44 \pm 0.51,83.73 \pm 0.64$ and $77.85 \pm 0.56 \%$ enzyme inhibitions respectively at $1 \mathrm{mg} / \mathrm{ml}$ concentration. These fractions were most potent among others with $\mathrm{IC}_{50}$ values of 45, 50 and $75 \mu \mathrm{g} / \mathrm{ml}$. AChE inhibitory activities of these fractions were comparable to standard drug galanthamine, whose percent inhibition was $96.00 \pm 0.30$ at the same tested concentration with $\mathrm{IC}_{50}$ of $20 \mu \mathrm{g} / \mathrm{ml}$. In BChE inhibition assay, Ir.Cf, Ir.Flv and Ir.EtAc were found 
most active causing $88.55 \pm 0.77,82.53 \pm 0.71$ and $72.66 \pm$ $0.78 \%$ enzyme inhibition at $1 \mathrm{mg} / \mathrm{ml}$ respectively. Median inhibitory concentrations $\left(\mathrm{IC}_{50}\right)$ for these fractions were 70,40 and $52 \mu \mathrm{g} / \mathrm{ml}$ respectively. Activities of these fractions were comparable to standard drug galanthamine at the same tested concentration. Among different fractions, Ir.Cf exhibited high phenolic $(82.60 \pm 0.68)$ and flavonoid $(91.45 \pm 1.12)$ contents, which can be linked to its highest enzyme inhibitory activities.

The use of antioxidants may slow the development of Alzheimer's disease (AD) and diminish neuronal degeneration $[35,36]$. Due to deteriorating effects of oxidative stress on human health the interest in naturally occurring antioxidant has been increased [37]. The flavonoids are reported to possess strong $\mathrm{BChE}$ inhibitory potential [38]. The age related brain performance can be improved by the use of vegetables and fruits rich in flavonoids which have the capability to neutralize the free radicals [39]. The total phenolic and flavonoid contents can be correlated with the antioxidant potential against free radicals which can lead to cognitive aging and CNS disorders [40]. Phenolic acids have been reported as natural radical scavengers in vegetables, fruits and herbs by several researchers [41]. The antioxidant potential of phenolics is attributed to their redox properties which enables them to give hydrogen or quench the singlet oxygen [42].

The concentrations of the crude plant extracts that inhibited the DPPH, $\mathrm{H}_{2} \mathrm{O}_{2}$ and ABTS radicals by $50 \%$ $\left(\mathrm{IC}_{50}\right)$ are presented in the Figure 1 . In DPPH free radicals scavenging assay, Ir.Sp, Ir.Flv, Ir.EtAc and Ir.Cf were found most potent with $\mathrm{IC}_{50}$ of 0.1, 19, 22 and $28 \mu \mathrm{g} / \mathrm{ml}$ respectively. In $\mathrm{H}_{2} \mathrm{O}_{2}$ scavenging assay, Ir.Flv, Ir.EtAc and $\mathrm{Ir}$.Cf proved $\mathrm{IC}_{50}$ of 24,30 and $34 \mu \mathrm{g} / \mathrm{ml}$ respectively. Likewise, in ABTS free radicals scavenging activity, $\mathrm{Ir}, \mathrm{Cr}$, Ir.Aq and Ir.Sp exhibited $\mathrm{IC}_{50}$ of 37, 55 and $70 \mu \mathrm{g} / \mathrm{ml}$ respectively. In Linear correlation of total phenolic contents vs $\mathrm{DPPH}, \mathrm{H}_{2} \mathrm{O}_{2}$ and ABTS radicals scavenging activities, these exhibited correlation coefficient of $\mathrm{R}^{2}=0.641,0.742$ and 0.415 respectively (Figure $5 \mathrm{C}, \mathrm{D}$ and $\mathrm{E}$ ). Concentrations of phenolics in different fractions correlated well to antioxidant and anticholinestrase activities. The current investigations suggest that I. rugosus is a good source of anticholinesterase and antioxidant compounds. The fractions showing highest activities should be further subjected to isolation of novel, cost effective and safer active compounds useful in the treatment of neurological disorders.

\section{Conclusion}

Based on the current investigations it may be concluded that the Ir.Flv, Ir.Sp and Ir.Cf isolated from I. rugosus exhibited anticholinesterase and antioxidant activities comparable to that of standard drugs which can be attributed to their high phenolic contents. The current study suggests further investigations of I. rugosus for isolation, purification and characterization of valuable bioactive compounds for the treatment of various neurodegenerative diseases.

\section{Methods}

\section{Plant collection and extraction}

The aerial parts of I. rugosus were collected from Dir (U) Khyber Pakhtunkhwa, Pakistan in May 2013. The plant was identified by plant taxonomist at the department of Botany, Shaheed Benazir Bhutto University, Sheringal Dir (U) KP, Pakistan. The plant specimen was deposited at the herbarium of the same University with voucher number (1016AZ). The plant material was cleaned from dust with tap water and then with distilled water till the complete removal of all the extra particles. It was spread on a clean paper and shade dried for 23 days. The plant material was converted into coarse powder with the help of a grinder. The powdered material (11 kg) was soaked in $80 \%$ methanol for 15 days and was filtered. The filtrated solution was concentrated under reduced pressure using rotary evaporator (Heidolph Laborota 4000 , Schwabach, Germany) at $40^{\circ} \mathrm{C}$. Finally, the crude methanolic extract (900 g) was obtained.

\section{Fractionation}

The crude methanolic extract having weight of $900 \mathrm{~g}$ was added to separating funnel and mixed with $500 \mathrm{~mL}$ of $n$-hexane, chloroform and ethyl acetate and fractionated by successive solvent-solvent extraction method starting from the low polar solvent towards the high polar solvent using method described previously [43]. Finally, Ir.Hex, Ir.Cf, Ir.EtAc and Ir.Aq obtained were $30 \mathrm{~g}$, $45 \mathrm{~g}, 50 \mathrm{~g}$ and $180 \mathrm{~g}$ respectively.

\section{Extraction of crude saponins}

Crude saponins from Isodon rugosus were extracted by adding $20 \mathrm{~g}$ of the plant sample in a conical flask having $100 \mathrm{~mL}$ of $20 \%$ ethanol. This mixture was heated on water bath at $55^{\circ} \mathrm{C}$ for $4 \mathrm{~h}$ followed by filtration. The residue obtained was extracted again with $200 \mathrm{~mL}$ of $20 \%$ ethanol and was added to the first collection. Volume of solvent extract was reduced to $40 \mathrm{ml}$ using water bath to obtained greenish color residue. The residue was transferred into a separating funnel and diethyl ether $(20 \mathrm{~mL})$ was added to it. After vigorous shaking, the separating funnel was put in a stand to get two layers. The upper organic layer was discarded while the lower aqueous layer obtained was diluted with $60 \mathrm{~mL}$ of $n$-butanol. This combined $n$-butanol extract was washed twice with $10 \mathrm{ml}$ of $5 \% \mathrm{NaCl}$ solution. The solution was evaporated by keeping in water bath to obtain the dried saponins [44]. 


\section{Extraction of crude flavonoids}

Harborne's procedure was followed for the isolation of crude flavonoids [45]. Plant sample having weight of $20 \mathrm{~g}$ was taken in powdered form and heated in $200 \mathrm{ml}$ of $2 \mathrm{M}$ $\mathrm{HCl}$ at $50^{\circ} \mathrm{C}$ under reflux for 30 minutes. It was allowed to cold and then filtered using whatman No.42 filter paper. The filtrate was treated with equal volume of ethyl acetate. The flavonoids present in the extract were precipitated, which was recovered with the help of weighed filter paper. The weight of flavonoids obtained was 1.5 grams (7.5\%).

\section{Determination of total phenolic contents}

The total phenolic contents was determined following the procedure reported previously [46]. Briefly, $1 \mathrm{ml}$ of diluted extract was mixed with $9 \mathrm{ml}$ of distilled water followed by addition of $1 \mathrm{ml}$ of Folin-Ciocalteu's reagent (FCR) with vigorous shaking. After $5 \mathrm{~min}, 10 \mathrm{ml}$ of $7 \%$ $\mathrm{Na}_{2} \mathrm{CO}_{3}$ solution was added to it and properly mixed. The mixture was diluted to $25 \mathrm{ml}$ with distilled water and shaken properly. After $90 \mathrm{~min}$, the absorbance was measured by using UV spectrophotometer at $750 \mathrm{~nm}$. Gallic acid standard curve was used for the measurement of total phenolic contents. The total phenolics were expressed as milligrams of gallic acid equivalent (mg GAE/g) per gram of dry sample.

\section{Determination of total flavonoids contents}

Total flavonoid contents of Isodon rugosus were determined using procedure previously described [47]. Briefly, $0.3 \mathrm{ml}$ of plant sample solution, $0.15 \mathrm{ml} \mathrm{NaNO} 2(0.5 \mathrm{M})$, $3.4 \mathrm{ml}$ methanol $(30 \%)$ and $0.15 \mathrm{ml} \mathrm{AlCl} 3.6 \mathrm{H}_{2} \mathrm{O}(0.3 \mathrm{M})$ were mixed and added to a $10 \mathrm{ml}$ test tube. After $5 \mathrm{~min}$, $1 \mathrm{ml}$ of $\mathrm{NaOH}(1.0 \mathrm{M})$ was added to it. The absorbance of the mixture was measured by using UV spectrophotometer at $506 \mathrm{~nm}$. For the determination of total flavonoids, standard Rutin solution curve (0 to $100 \mathrm{mg} / \mathrm{l})$ was used. The total flavonoid contents were expressed as milligram of rutin equivalent per gram of dry sample (mg RTE/g).

\section{Chemicals and drugs}

Potassium phosphate buffer ( $\mathrm{pH}$ 8.0), Galantamine from Lycoris Sp. (Sigma-Aldrich France), Butyrylthiocholin iodide (Sigma-Aldrich Switzerland), Acetylthiocholine Iodide (Sigma-Aldrich UK), 5,5-dithio-bis-nitrobenzoic acid (DTNB) (Sigma-Aldrich Germany), Electric eel acetylcholinesterase (type-VI-S, Sigma-Aldrich USA) and Aquine butyrylcholinesterase (Sigma-Aldrich USA) were used in enzyme inhibition assays. For antioxidant assays, DPPH (Sigma Aldrich CHEMIE GmbH USA), $\mathrm{H}_{2} \mathrm{O}_{2}$ (Riedel-de Haen Germany) and ABTS (SigmaAldrich Germany) were used. All solvents used in the assays were of analytical grades purchased from SigmaAldrich.

\section{Anticholinesterase assays}

In this method, plant samples were evaluated spectrophotometrically for $\mathrm{AChE}$ and $\mathrm{BChE}$ inhibition potentials using acetylthiocholine iodide and Butyrylthiocholine iodide as substrates, respectively following Ellman assay [48]. In this method, $205 \mu \mathrm{l}$ of plant samples $(125-1000 \mu \mathrm{g} / \mathrm{ml})$ were added to the cuvette contained $\mathrm{BChE}(0.01 \mathrm{U} / \mathrm{ml})$ and $5 \mu \mathrm{l}$ of AChE $(0.03 \mathrm{U} / \mathrm{ml})$. DTNB $(5 \mu \mathrm{l})$ was added to the mixture and incubated for $15 \mathrm{~min}$ in a water bath having temperature of $30^{\circ} \mathrm{C}$. To start the reaction added $5 \mu \mathrm{l}$ substrates to the mixture. Absorbance was measured using double beam Spectrophotometer at wavelength of $412 \mathrm{~nm}$ for $4 \mathrm{~min}$.

The reaction between thiocholines and DTNB was indicated by the formation of 5-thio-2-nitrobenzoate anion, which showed by yellow color appearance. White assay was carried out to check the hydrolysis of substrate contained no enzymes and plant samples. The reaction mixture containing without plant sample was taken as control. Percent enzyme activity and percent inhibition were calculated as follows;

$$
\begin{aligned}
& \mathrm{V}=\frac{\Delta \mathrm{Abs}}{\Delta \mathrm{t}} \\
& \% \text { enzyme activity }=\frac{\mathrm{V}}{\mathrm{V}_{\max }} \times 100 \\
& \% \text { enzyme inhibition }=100-\% \text { enzyme activity }
\end{aligned}
$$

(Where $\mathrm{V}$ indicates the rate of reaction in the presence of inhibitor and $V_{\max }$ is the rate of reaction without inhibitor).

\section{Antioxidant assays \\ $D P P H$ free radicals scavenging activity}

For DPPH free radicals scavenging activity the method of Brand-Williams et al. was followed with some modifications [49]. DPPH (24 mg) was dissolved in $100 \mathrm{ml}$ of methanol to prepare DPPH solution. The stock solutions of plant samples were prepared in methanol having concentrations of $1 \mathrm{mg} / \mathrm{ml}$ and then diluted to the concentrations $1000,500,250 \mu \mathrm{g} / \mathrm{ml}$. DPPH and sample solutions were mixed in a ratio of $1: 1$ and were incubated at $23^{\circ} \mathrm{C}$ for $30 \mathrm{~min}$. Finally, absorbance was measured at $517 \mathrm{~nm}$ using UV spectrophotometer (Thermo electron corporation USA). Ascorbic acid was used as positive control. Percent radical scavenging activity was measured using the following equation;

$$
\text { Scavenging effect } \%=\frac{\text { control absorbance-sample absorbance }}{\text { control absorbance }} \times 100
$$

\section{Hydrogen peroxide free radicals scavenging activity}

The plant samples were investigated for hydrogen peroxide free radical scavenging potential following the procedure of 
Ruch et al., [50]. Briefly, 2 mmol solution of hydrogen peroxide was prepared in $50 \mathrm{mmol}$ phosphate buffer having $\mathrm{pH}$ of 7.4. Various plant samples $(0.1 \mathrm{ml})$ were taken in test tubes followed by addition of $50 \mathrm{mmol}$ phosphate buffer to make the final volume $0.4 \mathrm{ml}$. Hydrogen peroxide $(0.6 \mathrm{ml})$ was added to the test tube and kept for $10 \mathrm{~min}$. Absorbance was measured spectrophotometrically at $230 \mathrm{~nm}$ against the blank. The hydrogen peroxide scavenging activity was calculated using the following equation;

Hydrogen peroxide scavenging activity $=\frac{1 \text {-sample absorbance }}{\text { control absorbance }} \times 100$

\section{ABTS free radicals scavenging activity}

Antioxidant potentials of Ir.Cr, Ir.Hex, Ir.EtAc, Ir.Cf, Ir. Aq, Ir.Flv and Ir.Sp were investigated using the free radicals of 2, 2-azinobis [3-ethylbenzthiazoline]-6-sulfonic acid (ABTS) [51]. ABTS (7 mmol) and potassium persulfate $(2.45 \mathrm{mmol})$ solutions were prepared and thoroughly mixed. For production of free radicals, the solution was kept in the dark for $8 \mathrm{~h}$ at room temperature. Prior to use, ABTS solution was diluted with Phosphate buffer (0.01 M), $\mathrm{pH}$ 7.4. The absorbance of ABTS solution was adjusted to 0.7 at $745 \mathrm{~nm}$ by the addition of $50 \%$ methanol. Radical scavenging ability of the fractions was analyzed by mixing $300 \mu \mathrm{l}$ of each test sample with $3.0 \mathrm{ml}$ of ABTS solution in a cuvette. The absorbance of the solution was measured using a double beam spectrophotometer for $6 \mathrm{~min}$. Ascorbic acid was used as positive control. The experiment was repeated three times and percent ABTS scavenging activity was calculated as follows;

Scavenging activity $(\%)=\frac{\text { control absorbance-sample absorbance }}{\text { control absorbance }} \times 100$

\section{Statistical analysis}

Each experiment was performed in three replicates and values were expressed as mean \pm SEM. One way ANOVA followed by multiple comparison Dunnett's test was used for the comparison of positive control with the test groups. The $\mathrm{P}$ values less than 0.05 were considered as statistically significant. $\mathrm{IC}_{50}$ values were calculated by a linear regression analysis among the percent inhibition against the extract concentrations via Excel program.

\section{Regression and linear correlation}

Regression (y) and linear correlation $\left(\mathrm{R}^{2}\right)$ for phenolic contents and various activities (anticholinesterase and antioxidants) were determined using Microsoft Excel 2007.

\section{Competing interests}

The authors declare that they have no competing interests.

\section{Authors' contributions}

AZ and SA carried out experimental work, data collection and literature search under the supervision of AS. FU helped as co-supervision of the research work. MA drafted the manuscript for publication. AS make the final version of publication. All the authors have read and approved the final manuscript for publication.

\section{Acknowledgements}

The authors are grateful to the Department of Pharmacy for the kind provision of research laboratories for conduction of these activities. We are also thankful to Dr. Ali Hazrat, Department of Botany, SBBU, Sheringal, Dir Upper, Pakistan for identification of plant.

\section{Funding}

This research received no specific grant from any funding agency in the public, commercial, or not-for-profit sectors.

Received: 8 September 2014 Accepted: 18 December 2014

Published: 26 December 2014

\section{References}

1. Kamal MA, Al-Jafari AA, Yu Q-S, Greig NH: Kinetic analysis of the inhibition of human butyrylcholinesterase with cymserine. Biochim Biophys Acta BBA-Gen Subj 2006, 1760(2):200-206.

2. Ellis JM: Cholinesterase inhibitors in the treatment of dementia. J Am Osteopath Assoc 2005, 105:145-158.

3. Giacobini E: Cholinesterase inhibitors for Alzheimer's disease therapy: from tacrine to future applications. Neurochem Int 1998, 32:413-419.

4. Krall W, Sramek J, Cutler N: Cholinesterase inhibitors: a therapeutic strategy for Alzheimer's disease. Ann Pharmacother 1999, 33:441-450.

5. Rahman A, Choudhary M: Bioactive natural products as a potential source of new pharmacophores a theory of memory. Pure Appl Chem 2001, 73:555-560.

6. Brenner G: Pharmacology. Philadelphia: WB Saunders Company; 2000.

7. Oh M, Houghton P, Whang W, Cho J: Screening of Korean herbal medicines used to improve cognitive function for anti-cholinesterase activity. Phytomedicine 2004, 11:544-548.

8. Schulz V: Ginkgo extract or cholinesterase inhibitors in patients with dementia: what clinical trial and guidelines fail to consider. Phytomedicine 2003, 10:74-79.

9. Watkins PB, Zimmerman HJ, Knapp MJ, Gracon SI, Lewis KW: Hepatotoxic effects of tacrine administration in patients with Alzheimer's disease. Jama 1994, 271:992-998.

10. Zhu X, Raina A, Lee H, Casadesus G, Smith M, Perry G: Oxidative stress signaling in Alzheimer's disease. Brain Res 2004, 1000:32-39.

11. Lobo V, Patil A, Phatak A, Chandra N: Free radicals, antioxidants and functional foods: impact on human health. Pharmacogn Rev 2010, 4(8):118-126.

12. Erejuwa O, Sulaiman SA, Wahab MS: Honey: a novel antioxidant. Molecules 2012, 17:4400-4423.

13. Zambonin L, Caliceti C, Sega F, Fiorentini D, Hrelia S, Landi L: Dietary phenolic acids act as effective antioxidants in membrane models and in cultured cells, exhibiting proapoptotic effects in leukaemia cells. Oxid Med Cell Longev 2012, 2012:1-12.

14. Gordon A, Cruz A, Cabral L, Cordeiro de Freitas S, Taxi C, Donangelo C: MChemical characterization and evaluation of antioxidant properties of Acai fruits (Euterpe oleraceae Mart.) during ripening. Food Chem 2012, 133:256-263.

15. Barlow S: Toxicological aspects of antioxidants used as food additives. In Food Antioxidants. Edited by Hudson BJF. London: Elsevier; 1990:253-307.

16. Zia-Ul-Haq M, Riaz M, De Feo V, Jaafar HZ, Moga M: Rubus fruticosus L.: constituents, biological activities and health related uses. Molecules 2014, 19(8):10998-11029.

17. Shah SM, Ayaz M, Khan A-u, Ullah F, lqbal H, Hussain S: 1, 1-Diphenyl, 2-picrylhydrazyl free radical scavenging, bactericidal, fungicidal and leishmanicidal properties of Teucrium stocksianum. Toxicol Ind Health 2013, doi:10.1177/0748233713487250.

18. Kil HY, Seong ES, Ghimire BK, Chung I-M, Kwon SS, Goh EJ, Heo K, Kim MJ, Lim JD, Lee D: Antioxidant and antimicrobial activities of crude sorghum extract. Food Chem 2009, 115:1234-1239.

19. Ayaz M, Junaid M, Ahmed J, Ullah F, Sadiq A, Ahmad S, Imran M: Phenolic contents, antioxidant and anticholinesterase potentials of crude extract, 
subsequent fractions and crude saponins from Polygonum hydropiper L. BMC Complement Altern Med 2014, 14:145.

20. Shahidi F, Wanasundara P: Phenolic antioxidants. Crit Rev Food Sci Nutr 1992, 32:67-103

21. Fujita E, Node M: Diterpenoids of Rabdosia species. In Fortschritte der Chemie organischer Naturstoffe/Progress in the Chemistry of Organic Natural Products. Vienna: Springer; 1984:77-157.

22. Faizul H, Habib A, Mukhtar A: Traditional uses of medicinal plants of Nandiar Khuwarr catchment (District Battagram), Pakistan. J Med Plants Res 2011, 5(1):39-48.

23. Collins M, Charles H: Antimicrobial activity of Carnosol and Ursolic acid: two anti-oxidant constituents of Rosmarinus officinalis L. Food Microbiol 1987, 4:311-315

24. Wojdyło A, Oszmiański J, Czemerys R: Antioxidant activity and phenolic compounds in 32 selected herbs. Food Chem 2007, 105:940-949.

25. Khan SW, Khatoon S: Ethnobotanical studies on useful trees and shrubs of Haramosh and Bugrote valleys, in Gilgit northern areas of Pakistan. Pak J Bot 2007, 39(3):699-710

26. Adnan M, Begum S, Khan AL, Tareen AM, Lee I-J: Medicinal plants and their uses in selected temperate zones of Pakistani Hindukush-Himalaya. J Med Plants Res 2012, 6:4113-4127.

27. Duh P-D, Tu Y-Y, Yen G-C: Antioxidant activity of water extract of Harng Jyur (Chrysanthemum morifolium Ramat). LWT-Food Sci Technol 1999, 32:269-277.

28. Hatano T, Edamatsu R, Hiramatsu M, Mori A, Fujita Y, Yasuhara T, Yoshida T, Okuda T: Effects of the interaction of tannins with co-existing substances. VI: effects of tannins and related polyphenols on superoxide anion radical, and on 1, 1-diphenyl-2-picryl hydrazyl radical. Chem Pharm Bull 1989, 37:2016-2021.

29. Decker M, Kraus B, Heilmann J: Design, synthesis and pharmacological evaluation of hybrid molecules out of quinazolinimines and lipoic acid lead to highly potent and selective butyrylcholinesterase inhibitors with antioxidant properties. Bioorg Med Chem 2008, 16:4252-4261.

30. Piazzi L, Belluti F, Bisi A, Gobbi S, Rizzo S, Bartolini M, Andrisano V, Recanatini M, Rampa A: Cholinesterase inhibitors: SAR and enzyme inhibitory activity of 3-[omega-(benzylmethylamino) alkoxy] xanthen-9ones. Bioorg Med Chem 2006, 15(1):575-585.

31. Kim W-G, Cho K-M, Lee C-K, Yoo I-D: Terreulactone A, a novel meroterpenoid with anti-acetylcholinesterase activity from Aspergillus terreus. Tetrahedron Lett 2002, 43:3197-3198.

32. Darvesh S, McDonald RS, Darvesh KV, Mataija D, Conrad S, Gomez G, Walsh $R$, Martin E: Selective reversible inhibition of human butyrylcholinesterase by aryl amide derivatives of phenothiazine. Bioorg Med Chem 2007, 15(19):6367-6378

33. Lobo V, Patil A, Phatak A, Chandra N: Free radicals, antioxidants and functional foods: Impact on human health. Pharmacog Rev 2010, 4:118

34. Schneider LS: New therapeutic approaches to Alzheimer's disease. J Clin Psychiatry 1995, 57:30-36.

35. Choudhary MI: Bioactive natural products as a potential source of new pharmacophores. A theory of memory. Pure Appl Chem 2001, 73:555-560.

36. Howes MJR, Perry NS, Houghton PJ: Plants with traditional uses and activities, relevant to the management of Alzheimer's disease and other cognitive disorders. Phytother Res 2003, 17:1-18.

37. Scalbert A, Manach C, Morand C, Rémésy C, Jiménez L: Dietary polyphenols and the prevention of diseases. Crit Rev Food Sci Nutr 2005, 45:287-306.

38. Noor A-t, Fatima I, Ahmad I, Malik A, Afza N, labal L, Latif M, Khan SB: Leufolins A and B, potent butyrylcholinesterase-inhibiting flavonoid glucosides from Leucas urticifolia. Molecules 2007, 12:1447-1454.

39. Youdim KA, Shukitt-Hale B, Joseph JA: Flavonoids and the brain: interactions at the blood-brain barrier and their physiological effects on the central nervous system. Free Radic Biol Med 2004, 37:1683-1693.

40. Golden TR, Hinerfeld DA, Melov S: Oxidative stress and aging: beyond correlation. Aging Cell 2002, 1:117-123.

41. Larson RA: The antioxidants of higher plants. Phytochemistry 1988, 27:969-978.

42. Rice-evans CA, Miller NJ, Bolwell PG, Bramley PM, Pridham JB: The relative antioxidant activities of plant-derived polyphenolic flavonoids. Free Rad Res 1995, 22:375-383.

43. Ayaz M, Junaid M, Subhan F, Ullah F, Sadiq A, Ahmad S, Imran M, Kamal Z, Hussain S, Shah SM: Heavy metals analysis, phytochemical, phytotoxic and anthelmintic investigations of crude methanolic extract, subsequent fractions and crude saponins from Polygonum hydropiper L. BMC Complement Altern Med 2014, 14:465.

44. Zeb A, Sadiq A, Ullah F, Ahmad S, Ayaz M: Phytochemical and toxicological investigations of crude methanolic extracts, subsequent fractions and crude saponins of Isodon rugosus. Biol Res 2014, 47(1):57.

45. Harborne A: Phytochemical methods a guide to modern techniques of plant analysis. London: Springer; 1998.

46. Kim D-O, Jeong SW, Lee CY: Antioxidant capacity of phenolic phytochemicals from various cultivars of plums. Food Chem 2003, 81(3):321-326.

47. Park H-H, Lee S, Son H-Y, Park S-B, Kim M-S, Choi E-J, Singh TS, Ha J-H, Lee M-G, Kim J-E: Flavonoids inhibit histamine release and expression of proinflammatory cytokines in mast cells. Arch Pharm Res 2008, 31(10):1303-1311.

48. Classics Ellman GL, Courtney KD, Andres V, Featherstone RM: A new and rapid colorimetric determination of acetylcholinesterase activity. Biochem Pharmacol 1961, 7:88-95.

49. Brand-Williams W, Cuvelier M, Berset C: Use of a free radical method to evaluate antioxidant activity. LWT-Food Sci Technol 1995, 28:25-30.

50. Ruch RJ, Cheng S-J, Klaunig JE: Prevention of cytotoxicity and inhibition of intercellular communication by antioxidant catechins isolated from Chinese green tea. Carcinogenesis 1989, 10:1003-1008.

51. Re R, Pellegrini N, Proteggente A, Pannala A, Yong M, Rice-Evas C: Antioxidant activity applying an improved FBTS radical cation decolorization assay. Free Rad Biol Med 1999, 26(9/10):1231-1237.

doi:10.1186/0717-6287-47-76

Cite this article as: Zeb et al:: Investigations of anticholinestrase and antioxidant potentials of methanolic extract, subsequent fractions, crude saponins and flavonoids isolated from Isodon rugosus. Biological Research 2014 47:76.

\section{Submit your next manuscript to BioMed Central and take full advantage of:}

- Convenient online submission

- Thorough peer review

- No space constraints or color figure charges

- Immediate publication on acceptance

- Inclusion in PubMed, CAS, Scopus and Google Scholar

- Research which is freely available for redistribution 